\title{
PEMANFAATAN BLOG MEDIA PEMBELAJARAN AGAMA HINDU
}

\author{
I Made Pustikayasa \\ STAHN-TP Palangka Raya \\ kuwud.it@gmail.com
}

\begin{abstract}
Riwayat Jurnal
Artikel diterima : -

Artikel direvisi : -

Artikel disetujui :-
\end{abstract}

\begin{abstract}
Abstrak
Teknologi Informasi dan Komunikasi (TIK) mengalami perkembangan setiap saat, sehingga berbagai informasi dapat diakses secara luas oleh setiap orang. Pemanfaatan TIK di Indonesia mengalami pertumbuhan dibergai sektor, salah satu indikator tersebut adalah pengguna internet meningkat setiap tahunnya yang menandakan betapa internet sangat berguna dalam kehidupan sehari-hari. Semakin banyaknya orang terhubung dengan internet,dunia pendidikan juga dapat memanfaatkannya sebagai media pembelajaran.Blogadalah salah satubagain integraldari TIK yang tehubung dengan internet yang merupakan layanan murah, efektif dan interaktif yang dapat dimanfaatkan sebagai media pembelajaran secara online oleh tenaga pendidik, karena pada sebuah konten blogdapat terjadi interkasi antara pemilik konten dan pengunjung blogsehingga akan terbangun hubungan timbal balik. Tidak hanya itu, seluruh informasiyang dibuat, diunggah (disimpan) juga dapat diakses dan dijadikan sumber belajar bagi masyarakat luas.
\end{abstract}

Kata Kunci: Internet, Blog, Media Pembelajaran, Agama Hindu

\section{Pendahuluan}

Dewasa ini perkembangan

Teknologi Informasi dan Komunikasi

(TIK) sudah semakin canggih sehingga dapat mempengaruhi gaya hidup masyarakat. Pengguna internet misalnya, hasil surveiAsosiasi Penyelenggara Jasa Internet Indonesia (APJII) dalam Penetrasi dan Perilaku Pengguna Internet Indonesia di tahun 2017 menunjukkan pengguna internet di Indonesia sudah lebih dari 50 persen dari populasi penduduk.

Dalam kemajuan TIK dan pengetahuan di masa global ini, tentu terkait dinamika pendidikan agama Hindu diharapkan dapat bersifat adaptif dan dinamis. Tidak bisa dalam pengelolaan pendidikan agama Hindu termasuk dalam 
strategi pembelajaran agama Hindu menjadi konyol dan bersifat pasif. Dalam mengimbangi kemajuan kekinian tersebut, sudah saatnya pengelolaan pendidikan agama Hindu selalu berinovasi, berkembang, dan mengikuti perkembangan kemajuan TIK dan kemajuan ilmu pengetahuan itu sendiri. Sama halnya dengan arus kemajuan TIK, ada beragam teknologi maju yang muncul, seperti: komputer, internet, gawaidan sebagainya, adalah selain media teknologi yang bersifat general atau untuk kepentingan publik, tetapi juga sebagai media pembelajaran bagi pembelajar(Subagiasta, 2010).Disamping itu penyebaraninformasi keagamaan Hindu yang bertujuan untuk meningkatkan sradha dan bhakti umat Hindu menjadi suatu tugas bersama dari yang memiliki kewenangan membimbing masyarakat Hindu di bawah Kementerian Agama dan semua stakeholder dari masyarakat Hindu sendiri yang memiliki kepentingan dan kemampuan dalam pembinaan masyarakat Hindu (Triyana, 2016). Karenanya, TIK menjadi sangat berperan dalam usaha penyebaran informasi keagamaan Hindu ke seluruh lapisan masyarat di Indonesia.Bagaimana tidak, selain sebagai penyerbar informasi keagamaan Hindu, TIK juga dapat dimanfaatkan sebagai media pembelajaran yang membantu tenaga pendidik dalam menciptakan lingkungan pembelajaran yang aktif, kreatif, efektif dan menyenangkan, serta mampu meningkankan motivasi dan memudahkan peserta didik dalam memahami materi yang disampaikan.

Berkenaan dengan pemanfaatan TIK dalam dunia pendidikan, UUNomor 14 Tahun 2005 tentang Guru dan Dosen juga menjelaskan seorang tenaga pendidikselain diwajibkan memiliki kualifikasi akademik, sertifikat pendidik, sehat jasmani dan rohani, serta memiliki kemampuan untuk mewujudkan tujuan pendidikan nasional.Tenaga pendidik wajib memiliki berbagai kompetensi diantaranya adalah kompetensi pedagogik. Kompetensi ini secara lebih rinci ditegaskan kembali dalam PMA Nomor 16 Tahun 2010 tentang Pengelolaan Pendidikan Agama Pada Sekolah, yang menjelaskan seorang guru (tenaga pendidik)harus memiliki kompetensi pedagogik,yaitu:(a) pemahaman karakteristik peserta didik dari aspek fisik, moral, sosial,kultural, emosional, dan 
intelektual; (b) penguasaan teori dan prinsip belajar pendidikan agama; (c) pengembangan kurikulum pendidikan agama; (d) penyelenggaraan kegiatan pengembangan pendidikan agama; (e). pemanfaatan TIK untuk kepentingan penyelenggaraan dan pengembangan pendidikan agama; (f) pengembangan potensi peserta didik untuk mengaktualisasikan berbagai potensi yang dimiliki dalam bidang pendidikan agama; (g) komunikasi secara efektif, empatik, dan santun dengan peserta didik; (h) penyelenggaraan penilaian dan evaluasi proses dan hasil belajar pendidikan agama; (i) pemanfaatan hasil penilaian dan evaluasi untuk kepentingan pembelajaran pendidikan agama; dan (j) tindakan reflektif untuk peningkatan kualitas pembelajaran pendidikan agama.

Dengannya,tenaga pendidik Agama Hindu pemanfaatan TIK wajib dilaksanakan untuk kepentingan penyelenggaraan dan pengembangan pendidikan agama Hindu dalam mencapai tujuan pendidikan. Dengan memanfaatkan TIK diharapkan konsep pendidikan Agama Hindu juga semakin berkembangdan perlahan beralih dari konsep pembelajaran berbasis teaching approachke konsep pembelajaran berbasis pada learning approach. Hal tersebut menuntut tenaga pendidik mampu menggunakan media pembelajaran yang sesuai perkembangan TIK, setidaknya dapat menggunakan media pembelajaran yang mudah, murah dan efisien meskipun sederhana namun dapat mencapai tujuan pembelajaran yang diharapkan, Hamalik dalam (Kustandi \& Sutjipto, 2013, pp. 67).

Berpijak pada meningkatnya populasi pengguna internet dan pentingnya penyebaran informasi keagamaan Hindu keseluruh lapisan masyarakat serta tuntutan pemanfaatan TIK dalam penyelenggaraan pendidikan agama oleh PMA, seorang tenaga pendidik dalam melaksanakan pembelajaran harus memiliki gagasan yang ditunjukkan dalam desain pembelajaran, sebagai titik awal dalam melaksanakan komunikasi dengan peserta didik, karena proses belajar tidak selamanya hanya bersentuhan dengan halhal yang konkrit, baik dalam konsep maupun faktanya. Bahkan dalam kenyataan, belajar seringkali bersentuhan dengan hal-hal yang bersifat kompleks, maya dan berada di balik realitas, karena 
itu media memiliki andil untuk menjelaskan hal-hal yang abstrak dan menunjukkan hal-hal tersembunyi, ketidakjelasan atau kerumitan bahan ajar dapat di bantu dengan menghadirkan media sebagai perantara, bahkan dalam hal tertentu media dapat mewakili kekurangan tenaga pendidik dalam mengkomunikasikan materi pelajaran (Sutikno \& Sobry, 2007, p. 173).

Blogatau web log merupakan bagian integral dari TIK yang dapat dimanfaatkan sebagai media pembelajaran online yang murah, efektif dan dapat dijadikan sebagai sarana penyebaran informasi keagamaan Hindu ke seluruh lapisan masyarakat indonesia bahkan diseluruh penjuru dunia, selama terhubung dengan internet.

\section{Pembahasan}

\subsection{Media Pembelajaran}

Kegunaan media pembelajaran sangat dipengaruhi oleh ruang, waktu, pendengar (penerima pesan atau peserta didik) serta sarana dan prasarana yang tersedia, disamping sifat dari media pembelajaran.Penggunaan media pembelajaran diartikan sebagai segala sesuatu yang dapat digunakan untuk menyalurkan pesan atau isi pelajaran, merangsang pikiran, perasaan, perhatian dan kemampuan siswa, sehingga dapat mendorong proses belajarmengajar(Ibrahim \& Syaodih, 2003, p. 112).

Menurut pendapat Miarso(2004, p. 458), media pembelajaran merupakan segala sesuatu yang digunakan untuk menyalurkan pesan serta dapat merangsang pikiran, perasaan, perhatian dan kemauan si belajar sehingga dapat mendorong terjadinya proses belajar yang disengaja, bertujuan dan terkendali.Selanjutnya menurut pendapat Sadiman (2008, p. 7), media pembelajaran adalah segala sesuatu yang dapat digunakan untuk menyalurkan pesan dari pengirim ke penerima sehingga dapat merangsang pikiran, perasaan dan minat serta perhatian mahasiswa sedemikian rupa sehingga proses belajar terjadi.

Berdasarkan pendapat Miarso, Sadiman dan Ibrahim \& Syaodih maka yang dimaksud dengan media pembelajaran merupakan segala sesuatu yang dapat digunakan untuk membantu proses pembelajaran dalam penyampaian pesan kepenerima pesan sehingga dapat merangsang pikiran, perasaan, perhatian, minat dan kemampuan penerima pesan 
sehingga dapat mendorong proses belajar mengajar menjadi lebih efektif. Karenanya,Media pembelajaran hendaknya dapat memberikan pengalaman yang menyenangkan dan memenuhi kebutuhan pelajar yang memiliki kemampuan berbeda-beda,untuk itu tenaga pendidik harus memiliki pengetahuan dan pemahaman yang cukup tentang media pembelajaran, meliputi: (a) Media sebagai alat komunikasi guna lebih mengefektifkan proses belajar mengajar; (b) Fungsi media dalam rangka mencapai tujuan pendidikan; (c) Seluk-beluk proses belajar; (d) Hubungan antara metode mengajar dan media pembelajaran; (e) Nilai atau manfaat metode pendidikan dalam pembelajaran; (f) Pemilihan dan penggunaan media pendidikan; (g) Berbagai jenis alat dan teknik media pendidikan;(h) Media pendidikan dalam setiap mata pelajaran; (i). Usaha inovasi dalam media pendidikan. Berdasarkan penjelasan tersebut tenaga pendidik diharapkan dapat berinovasi dalam memilih dan memanfaatkan media pembelajaran yang murah, efektif, efisien sehingga tujuan pembelajaran dapat tercapai dengan baik. Karena menurut Djamarah\& Zain (1995, p. 136)dalam proses belajar mengajar kehadiran media mempunyai arti yang cukup penting karena dalam kegiatan pembelajaran ketidakjelasan bahan yang disampaikan dapat dibantu dengan menghadirkan media sebagai perantara. Kerumitan bahan yang akan disampaikan dapat disederhanakan dengan bantuan media. Media dapat mewakili apa yang kurang mampu pendidik ucapkan melalui katakata atau kalimat tertentu. Bahkan keabstrakan bahan dapat dikonkretkan dengan kehadiran media. Dengan demikian, peserta didik akan lebih mudah mencerna dengan media dari pada tanpa bantuan media pembelajaran.

Penggunaan media pembelajaran yang tepat akan memberi dampak yang sangat baik bagi peserta didik, sebagaimana hasil penelitian Kemp and Dayton (1985, pp. 3-4) yang mengemukakan dampak positif dari penggunaan media pembelajaran sebagai bagian integral pembelajaran atau sebagai cara utama pembelajaran langsung yaitu: (a) Penyampaian pelajaran tidak kaku;(b) Pembelajaran bisa lebih menarik;(c) Pembelajaran menjadi lebih interktif dengan diterapkanya teori belajar dan prinsip-prinsip psikologis yang diterima 
sebagain umpan balik atau penguatan;(d) Lama waktu pembelajaran yang diperlukan dapat dipersingkat kerena kembanyakan media memerlukan waktu singkat untuk mengantarkan informasi dan isi pelajaran dalam jumlah cukup banyak, dan memungkinkan dapat diserap oleh pelajar;(e) Kualitas hasil belajar dapat ditingkatkan bila integrasi kata dan gambar sebagai media pembelajaran dapat mengkomunikasikan elemen-elemen pengetahuan dengan cara yang terorganisasi dengan baik, spesifik dan jelas;(f) Pembelajaran dapat dapat diberikan kapan saja dan dimana saja diinginkan atau diperlukan, terutama media pembelajaran dirancang untuk penggunaan secara individu;(g) Sikap positif pelajar terhadap apa yang mereka pelajari dan terhadap proses belajar dapat ditingkatkan;(h) Peran pengajar dapat berubah kearah yang lebih positif.

\subsection{Korelasi Penggunaan Internet}

\section{Terhadap Media Blog}

Karena blog merupakan layanan bersifat online sehingga membutuhkan internet sebagai penghubung antara pemilik dan pengunjung blog. Seiring dengan meningkatnya penggunaan internet di Indonesia, penggunaan blog sebagai media pembelajaran menjadi sangat relevan.Hal ini ditunjukkan oleh hasil survei APJII bahwa pengguna internet di Indonesia sudah mencapai 143 juta jiwa yang artinya mengalami peningakatan dari tahun ke tahun yaitu 54,6 persendari 262 juta jiwa jumlah populasi penduduk Indonesia telah terhubung jaringan internet dan mayoritas pengguna internet sebanyak 72,41 persen masih dari kalangan masyarakat urban. Pemanfaatannya sudah lebih jauh, tidak hanya untuk berkomunikasi tetapi juga membeli barang, memesan transportasi, hingga berbisnis dan berkarya. Banyak inovasi internet tak bisa dipisahkan dari kehidupan sehari-hari masyarakat Indoensia, jika ditinjau dari segi usia, ada sebanyak 49,52 persen pengguna internet berusia 19 hingga 34 tahun, 29,55 persen pengguna internet Indonesia berusia 35 hingga 54 tahun. 16,68 persen adalah pengguna internet berusia remaja antara 13 hingga 18 tahun dan sisanya 4.24 persen adalah orang tua yang berusia di atas 54 tahun.

Selain usia tingkat pendidikan terakhir juga memengaruhi penetrasi penggunaan internet di Indonesia, yakni: 88,24 persen bergelar pendidikan S2 dan 
S3, 79,23 persen lulusan S1 dan Diploma, sedangkan tingkat pendidikan sampai SMA/MA/Paket C, SMP/MTs/Paket B, $\mathrm{SD} / \mathrm{MI} /$ Paket $\mathrm{A}$, dan pengguna internet yang tidak sekolah, persentase pengguna internetnya secara berurutan 70,54 persen, 48,53 persen, 25,10 persen, dan 5,45 persen (Penetrasi dan Perilaku Pengguna Internet Indonesia, 2017). Saat ini di universitas dan akademi kejuruan, internet telah menjadi bagian penting dari proses belajar-mengajar, sebagai contoh: tugas dan ujian dikumpulkan melalui surel (email) dalam bentuk softcopy, bukan lagi berbentuk cetak (hardcopy). Tidak hanya itu, mencari referensi pun kerap dilakukan penelusuran dari jurnal online atau eBook.

\subsection{MediaBlog}

Pada saat ini hadirnya TIK, paradigma dalam dunia pendidikan menghadapi dua tantangan yakni perubahan pandangan terhadap belajar dan kemajuan TIK yang menawarkan berbagai kemudahan dalam pembelajaran yang menyebabkan terjadinya pergeseran orientasi belajar yaitu: belajar dariluar(outside-guided) menjadi belajar dari diri sendiri (self-guided).Menurut Rouf dan Sopyan (2007), blog adalah suatu laman (situs) online yang berfungsi sebagai media jurnal/diari bagi seseorang. Jovan(2007) menambahkan bahwa blog adalah " a personal diary, a daily pulpit, a collaborative space, a political soapbox, a breaking-news outlet, a collection of links, one's own private thoughts, and memos to the world". Graham (2005)juga menyatakan bahwa membuat blog tidaklah sulit karena hanya memerlukan pemahaman sederhana mengakses internet, sama mudahnya untuk membuat danmengirimemail.Membuatblog tidak memerlukan.

Pemahamanakan bahasa pemrograman atau sintaks-sintaks pemrograman yang rumit karena semua sudah dikerjakan oleh sistem. Sedangkan menurut Sumawung (2012)blog adalah sebuah website dinamis yang berisi aneka link dan komentar dari pengunjung atau pemilik itu sendiri. Dengan demikian blog merupakan layanan online murah bahkan gratis berupa halaman web yang dimanfaatkan dan kelola oleh setiap orang (blogger) untuk menuangkan dan menyimpan hasil pemikiran atau gagasan atau artikel, video, tautan (link) terhadap karya orang lainyang dapat diakses oleh seluruh pengguna internet, 
dengannyaakan terjadi interaksi antara blogger dengan pengguna internet (pengunjungblog). Karena sifatnya yang dinamis maka pengelola blog dapat mengupdate ataumemperbaharui konten maupun themplate-nya.

Secara umum blogdigunakan sebagai media arsip penyimpan data atau pengingat seperti catatan harian, artikel, tutorial secara online yang dapat dipublikasikan dan dapat diakses oleh seluruh pengguna internet dari manapun.Blogjuga mempunyai fungsi yang sangat beragam, selain hanya sebagai sebuah catatan harian, juga berfungsi sebagai media publikasi dalam sebuah kampanye politik, sampai dengan program-program media dan perusahaanperusahaan. Sebagian blogdapat kelola oleh seorang penulis tunggal, atau beberapa penulis. Banyak juga blog yang memiliki fasilitas untuk interaksi dengan para pengunjung, seperti menggunakan buku tamu dan kolom komentar yang dapat memperkenankan pengunjungnya untuk meninggalkan komentar atas isi dari konten blog yang dipublikasikan pengelolanya, namun demikian ada juga blog yang bersifat sebaliknya (noninteraktif).
Media

blog

pertama kalidipopulerkan oleh blogger.com, yang dimiliki oleh PyraLab dan sekarang sudah diakuisisi oleh Google Inc pada akhir tahun 2002. Semenjak itu, banyak terdapat layanan sejenis yang bersifat sumber terbuka yang diperuntukkan kepada perkembangan para penulis blog tersebut(Kristiyanti, 2011). Tidak hanya blogger.com, kini banyak layanan bloggratis yang dapat dimanfaatkan sebagai media pembelajaran antara lain: wordpress.com, weebly.com, lifejournal.com dan masih banyak lagi layanan bloglain.

Sebagian besar pengguna internet pasti sudah tahu apa itu blogger.com,namun bagi pengguna internet pemula blogger.com/blogspot.com adalah salah satu layanan weblog hosting yang menyediakan aplikasi web dalam bentuk blogdi bawah naungan Google Inc.Di dalam blogger atau blogspot penulis/pengelola blogjuga diberikan keluasaan melalukan perubahan desain templateyang disediakan sesuai keinginannya (Enterprise, 2016). Dengan demikian blogger.com adalah salah satu layanan blogpopuler yang dapat 
digunakan sebagai media pembelajaran, dengan dua alasan yaitu: (1) Gratis dan praktis, karena hanya perlu memiliki akun Gmail (surel)pada Google untuk membangun sebuah blog; (2) Fitur yang lengkap dan mudah digunakan(Helianthusonfri, 2017).

\subsection{Pengembangan Blog Sebagai Media}

\section{Pembelajaran Agama Hindu}

Dalam pengembangan blogsebagai media pembelajaran ada beberapa hal yang perlu dilakukan agar setiap konten blog dapat dimanfaatkan dalam pembelajaran, yaitu:

1. Tema blog

Tema sebuah blog sangat penting ditentukan diawal pembuatan blogdan fokus pada satu tema bahasan saja dan lebih spesifik yaitu berkaitan dengan Agama Hindu;

2. Kontenblog

Untuk mendukung proses pembelajaran, tenaga pendidik harus mengisi dan mempublikasikan konten blog yang hanya berkaitan dengan tema atau materi pelajaranyang sesuai dengan kebutuhan peserta didik, seperti: silabus, materi dan soal, akan tetapi blog tetap dapat menjadi sumber pengetahuan bagi masyarakat umum. Tidak hanya itu, untuk memenuhi konten blogsebagai media pembelajaran, konten harus menarik dan interaktif sehingga membangun komunikasi antara tenaga pendidik dan peserta didik.

3. Menu atau navigasi blog

Menu atau navigasi pada sebuah blog merupakan sebuah petunjuk berupa tautan untuk menuju ke bagian tertentu pada sebuah blog, karenanya navigasi blogharus jelas agar memudahkan pengunjung dalam menelusuri konten yang ada.

4. Menautkan blog dengan media sosial Menautkan blog dengan media sosial (facebook, Twitter, dll) akan memudahkan pengunjung untuk menemukan konten blog, selain itu menautkan blog dengan media sosial juga sangat bermanfaat sebagai tempat promosi konten blog.

5. Publikasi tautan (link) blog sejenis. Dengan adanya publikasi tautan blog lain yang sejenis dalam hal ini adalah yang berkaitan dengan keagamaan Hindu, tidak hanya sebagai bahan referensi, tetapi juga memudahkan pengujung blogmenuju pada sumber belajar yang lebih bervariasi. 
6. Bahasa konten sebuah blog. Blogsecara umum menggunakan bahasa yang ringan, sederhana dan mudah dimengerti oleh pengujung, namun tidak mengabaikan kaidah dalam sebuah kalimat. Karenanya, dalam membuat sebuah konten sangat perlu memperhatikan penggunaan bahasa yang tepat agar pengunjung menjadi tertarik untuk membaca dan berkunjung kembali di kemudian hari, bahkan membagikan ke media sosial.

7. Desain blog(themes / themplate)

Desain blogjuga merupakan hal yang perlu diperhatikan, karena desain yang sesuai dengan tema, mudah diakses dengan koneksi internet yang rendah sehingga tidak memerlukan pemuatan (loading) laman blog tidak terlalu lama.

\section{Search Engine Optimation (SEO)}

SEO perlu diterapkan pada sebuah bloguntuk meningkatkan posisi konten blog pada mesin telusur (search engine) seperti google, yahoo, bing dan lain-lain.

\subsection{Manfaat Blog Sebagai Media Pembelajaran}

Dengan menggunakan blogsebagai media pembelajaran tenaga pendidik dapat menyampaikanbahan pengajaran, memberikan alternatif cara mengakses sumber-sumber informasi lain secara tanpa batas dan menawarkan sumber pengayaan bahan dari beragam informasi yang sedang berkembang secara cepat setiap harinya. Blog juga sekaligus berfungsi sebagai media interaksi dan berdiskusi antara tenaga pendidik dengan peserta didik, antar tenaga pendidik, antar peserta didik dan seterusnya(Hasan, Rahman, \& Anis, 2017). Dengan memanfaatkanblog sebagai medianya, pembelajaran dengan scientificapproach melibatkan peserta didik,dan diberikan kesempatan dalam kelompok-kelompok untuk dapat membagi informasi yang diperolehnya melalui penyampaian hasil diskusi. Model pembelajaran ini menjadikan peserta didik dalam pembelajaran yang lebih aktif karena selama berlangsungnya pembelajaran peserta didik yang menjadi subyek belajar. Peserta didik yang mencari, mengolah dan menyampaikan informasi yang diperolehnya melalui presentasi dari 
perwakilan anggota masing-masing kelompok serta mendorong komunikasi antar peserta didik yang dapatmeningkatkan prestasi belajar (Rustam Abdillah, 2017).

Mutiara Sekar Ayu (2016)dalam penelitiannya tentang Pengembangan Blog Sebagai Sumber Belajar Mata Pelajaran Tata Hidang Kelas Xi Smk N 1 Kalasan juga menunjukkan hasil bahwa blogsangat layak digunakan sebagai media pembelajaran.

Dari pendapat dan hasil penelitian di atas dapat disimpulkan, pemanfaatkanblog sebagai media pembelajaran memiliki manfaat, yaitu:

1. Sebagai arsip online, dan dapat dimanfaatkan berulang bahkan selamanya;

2. Menjadi media interaksi dan komunikasi antar tenaga pendidik dengan peserta didik tanpa harus bertemu langsung;

3. Pembelajaran menjadi lebih interaktif;

4. Menambah wawasan di bidang TIK

5. Sebagai sumber informasi bagi tenaga pendidik dan pesesrta didik juga masyarakat umum.

\subsection{Kelebihan dan Kekurangan Media Blog}

Menurut Oya Suryana dalam (Resto Waty, 2016, pp. 19-20)media blogmemiliki kelebihan,yakni: (1) Selain karena sifatnya yang ada dalam jaringan internet, beberapa kelebihan dari blog lainya adalah sifatnya berdiri sendiri sebagai media; (2) Pengguna blog bebas dan cenderung penggunaan bahasa nonformal yang baik dan positif yang dipakainya; (3) Blog memungkinkan terjadinya interaktifitas antara sumber dengan penerima informasi. Informasi yang disampaikan akan langsung direspon, ditambahi, dikoreksi dan diperkaya oleh orang lain. Oleh karena itu, suatu topic mungkin bisa menjadi lebih menarik dengan adanya diskusi antara blogger dengan pengunjung blognya; (4) Blog adalah media yang digunakan secara personal, baik individual maupun institusional. Tidak ada persyaratan personal yang diberikan dari orang lain untuk bisa memiliki dan mengelola blog sendiri; (5) Formatnya yang mudah diaplikasikan dan pengelolaannya yang tidak rumit membuat media ini bisa dioperasikan oleh siapapun; (6) Blog dapat 
diakses oleh siapa saja dan dari kalangan mana saja. Tidak diperlukan kemampuan khusus teknis atau kemampuan dasar jurnalisme untuk mempublikasikan informasi dalam blog; (7) Meningkatkan prestasi belajar dan meningkatkan wawasan. melalui blogberagam informasi yang dibutuhkan dapat diperoleh sebagai sumber belajar; (8) Meningkatkan efisiensi pembelajaran bidang pendidikan; (9) Dalam bidang pendidikan peran pendidik juga dapat digantikan dengan adanya blog. Tidak semua hal dapat dijelaskan oleh pendidik karena keterbatasan waktu, sehingga dapat mencari jawabannya di blog; (10) Meningkatkan rasa percaya diri. Blog juga dapat dimanfaatkan untuk media publikasi bebagai karya tulis, sepert: puisi, cerpen, opini, artikel dan lain sebagainya yang nantinya akan dinilai oleh orang lain melalui kolom komentar.

Demikian juga kelebihan pemanfaatan internet sebagai media pembelajaran yakni:

Dimungkinkanterjadinya distribusi pendidikan ke semua penjuru tanah air dan kapasitas daya tampung yang tidak terbatas karena tidak memerlukan ruang kelas; (2) Proses pembelajaran tidak terbatas oleh waktu seperti halnya tatap muka biasa; (3) Pembelajaran dapat memilih topik atau bahan ajar yang sesuai dengan keinginan dan kebutuhan masingmasing; (4) Lama waktu belajar juga tergantung pada kemampuan masingmasing peserta didik; (5) Adanya keakuratan dan kekinian materi pembelajaran; dan (6) Pembelajaran dapat dilakukan secara interaktif, sehingga menarik peserta didik; dan memungkinkan pihak berkepentingan (orang tua peserta didik maupun tenaga pendidik) dapat turut serta menyukseskan proses pembelajaran, dengan cara memeriksa tugas-tugas yang dikerjakan peserta didik secara online(Sari, Hudiyono, \& Soe'oed, 2017).

Dengan demikian pemanfaatan blogsebagai media pembelajaranmemiliki beberapa kelebihan; yakni: murah, mudah, sederhana dan tidak memerlukan keahlian khusus (seperti menguasai bahasa pemrograman) untuk mengelolanya.

Di sisi lain pembelajaran menggunakan media blogjuga memiliki kelemahan yaitu: (1) Blogsangat tergantung pada koneksi internet; (2) Memerlukan perangkat untuk mengakses blogseperti komputer dan 
gawai. Menurut Oya Suryana dalam (Resto Waty, 2016, p. 20) juga menjelaskan beberapa kelemahan blog, yakni: (1) Beberapablog rentan terkena virus, hacker atau spywere; (2) Kurangnya sentuhan manusiawi, mudah disalahgunakan, dan konten yang ada di dalam blog kurang dapat dipertanggung jawabkan; (3) Rawan copypaste dalam media pembelajaran, blog akan membuat peserta pendidik kecanduan dan selalu mengandalkan blogketika mencari materi pelajaran; (4) Apabila sebuah postingan blog berisi konten negatif, maka pengunjung blogdapat terpapar pengaruh negetif,terutama anak-anak yang berusia dibawa umur.

Untuk menimalisir kelemahan media blog ada beberapa upaya yang dapat dilakukan, yakni : (1) Memanfaatkan dan menggunakan sistem keamanan yang disediakan dalam layanan bloguntuk menghindari kemungkinan kena virus, hack dan spyware, contoh : mengunakan kata sandi (password)yang tidak mudah ditebak orang lain, mencantumkan nomor telepon aktif sebagai verifikasi keamanan ganda; (2)Menggunakan desain menarik, dan memiliki kontrol yang jelas benarterhadap konten dan moderasi komentar yang akan dipublikasi untuk menghindari adanya pengaruh negatif yang akan ditimbulkan; (3) Sedangkan dalam media pembelajaran, jadikan konten blog tidak mudah di copypaste; (4) Peran pendidik dan oranga tua dalam mengontrol blog yang kemungkinan berisi konten negatif.

\section{Penutup}

Sangat disadari bahwa selama ini agama Hindu tidak anti terhadap kemajuan TIK dan ilmu pengetahuan. Tenaga pendidik yang proaktif dalam memilih dan menerapkan TIK sebagai media pembelajaran agama Hindu maka dinamika pendidikan, pembelajaran, dan pengajaran agama Hindu diyakini mengalami perkembangn dan kemajuan yang signifikan. Pemanfaatan blog sebagai sebagai media pembelajaran sekaligus sebagai sumber belajar sedikitnya akan mengubah cara belajar dan teknik pembelajaran agar tidak monoton sehingga dapat memotivasi pembelajar dalam mempelajari sesuatu melali blog.

Dengan kemampuan membuat blog sebagai media pembelajaran peserta didik dapat menerima informasi seluas-luasnya dari berbagai sumber sekaligus 
memberikan feedback tanpa harus berhadapan langsung dengan tenaga pendidik.

Dalam konteks pembelajaran, blog menawarkan kemungkinan peserta didik untuk belajar kolaboratif dengan berbagi pengetahuan dan pengalaman satu sama lain, lebih aktif mendapatkan keragaman perspektif dan berinteraksi dengan cara yang konstruktif.

\section{Daftar Pustaka}

Djamarah, S. B., \& Zain, A. (1995). Strategi Belajar Mengajar. Jakarta: Rineka Cipta.

Enterprise, J. (2016). Membuat Blog Dengan Blogger. Jakarta: Elex Media Komputindo.

Graham, S. (2005). Blogging for ELT. Retrieved August 17, 2018, from https://www.teachingenglish.org.uk/ article/blogging-elt

Hasan, H., Rahman, A., \& Anis, M. (2017). Pelatihan Pembuatan Blog Sebagai Media Pembelajaran Bagi Guru Sejarah di SMA Negeri 1 dan SMA Negeri 3 Langsa. In Proceeding Seminar Nasional Politeknik Negeri Lhokseumawe (Vol. 1, pp. 321-324). Helianthusonfri, J. (2017). Website Canggih dan Praktis dengan Blogspot. Jakarta: Alex Media Computindo.

Ibrahim, R., \& Syaodih, N. (2003).

Perencanaan Pengajaran. Jakarta: Renika Cipta.
Jovan, F. (2007). Panduan Praktis Membuat Web dengan PHP untuk Pemula. Jakarta: Media Kita.

Kemp, J.E., \& Dayton, O. K. (1985). Planning and Prducing Instructional Media. New York: Harper and Row.

Kristiyanti, M. (2011). Blog Sebagai Alternatif Media Pembelajaran. Majalah Ilmiah Informatika, 2, 3345.

Kustandi, C., \& Sutjipto, B. (2013). Media Pembelajaran Manual dan Digital. Bogor: Ghalia Indonesia.

Miarso, Y. (2004). Menyemai Benih Teknologi Pendidikan. Jakarta: Kencana.

Penetrasi dan Perilaku Pengguna Internet Indonesia. (2017). Retrieved from https://www.apjii.or.id/

Resto Waty, B. (2016). Pengembangan Media Pembelajaran Dekorasi Birthday Cake Dengan Butter Cream Menggunakan Blog Internet Pada Siswa SMKN 6 Yogyakarta. Yogyakarta.

Ruof, I., \& Soyan, Y. (2007). Panduan Praktis Mengelola Blog. Jakarta: Media Kita.

Rustam Abdillah, S. J. \& L. N. (2017). Pemanfaatan Blog Sebagai Media Pembelajaran Dalam Meningkatkan Prestasi Belajar Siswa.

Sadiman, A. S., \& Dkk. (2008). Media Pendidikan

Pengembangan

Pengertian,

Pemanfaatannya. dan RajavGrafindo Persada.

Sari, R., Hudiyono, Y., \& Soe'oed, R. (2017). Pengembangan Media Blog 
Dalam Pembelajaran Menulis Teks Anekdot Pada Siswa Kelas X SMA. Ilmu Budaya, 1, 317-330.

Sekar Ayu, M., \& Rahmawati M.P., F. (2016). Pengembangan Blog Sebagai Sumber Belajar Mata Pelajaran Tata Hidang Kelas Xi SMK N 1 Kalasan. Jurnal Pendidikan Teknik Boga, 1-9. Subagiasta, I. K. (2010). Inovasi Pembelajaran Agama Hindu. Retrieved August 18, 2018, from http://phdi.or.id/artikel/inovasipembelajaran-agama-hindu-2

Sumawung, T. (2012). Menulis di Blog Bisa Bikin Kaya Menciptakan Ladang Bisnis Online. Jakarta: Indeks.

Sutikno, M., \& Sobry. (2007). Menggagas Pembelajaran Efektif dan Bermakna. Mataran: NTP Pres.

Triyana, I. G. N. (2016). Perkembangan Media Keagamaan Hindu Berbasis Teknologi Informasi. Vidya Samhita, II(2), 85-90. 